\title{
Horizontal transmission of epizootic ulcerative syndrome (EUS)-associated virus in the snakehead Ophicephalus striatus under simulated natural conditions
}

\author{
Gilda D. Lio-Po ${ }^{1, *}$, Lawrence J. Albright ${ }^{2}$, Garth S. Traxler ${ }^{3}$, Eduardo M. Leaño ${ }^{1}$ \\ ${ }^{1}$ Aquaculture Department, Southeast Asian Fisheries Development Center, Tigbauan, Iloilo 5021, Philippines \\ ${ }^{2}$ Department of Biological Sciences, Simon Fraser University, Burnaby, British Columbia V5A 1S6, Canada \\ ${ }^{3}$ Pacific Biological Station, Nanaimo, British Columbia V9R 5K6, Canada
}

\begin{abstract}
Natural transmission of the epizootic ulcerative syndrome (EUS) was conducted on naïve snakeheads Ophicephalus striatus (also known as Channa striata) kept (A) in aquifer water, (B) in lakewater, (C) cohabiting with EUS snakeheads in lakewater, and (D) cohabiting with apparently healthy snakeheads in lakewater during the 1994 to 1995 EUS season. The results showed that EUS-like lesions developed in 6 to $14 \mathrm{~d}$ among naïve snakeheads cohabiting with EUS snakeheads and with apparently healthy snakeheads in lakewater (Treatments C and D). Among naïve fish exposed to lakewater (Treatment B), similar lesions developed in 16 to $21 \mathrm{~d}$, while naïve fish in aquifer water (Treatment A) did not develop EUS-like lesions. EUS signs began as Grade I (slight) lesions that gradually progressed to Grades III-IV (severe) 3 to $5 \mathrm{~d}$ from lesion onset, similar to the naturally affected EUS fish. The virus was recovered from some but not all naturally EUS-affected snakeheads, snakeheads with healing lesions and apparently healthy snakeheads, but not from naïve snakeheads. The results provide evidence of a waterborne horizontal transmission of the EUS-associated virus. This is the first report of a successful horizontal transmission of the EUSassociated virus from apparently healthy snakeheads to naïve fish under natural conditions and of virus recovery in tissue culture from naturally exposed experimental fish.
\end{abstract}

KEY WORDS: Epizootic ulcerative syndrome $\cdot$ EUS) $\cdot$ Rhabdovirus $\cdot$ Snakehead $\cdot$ Cohabitation · Virus recovery

Resale or republication not permitted without written consent of the publisher

\section{INTRODUCTION}

The epizootic ulcerative syndrome (EUS) is a serious disease that affects many wild and cultured freshwater fishes in the Philippines and in other Asian countries (Lilley et al. 1998). Fish species commonly affected by this syndrome are snakeheads Ophicephalus striatus (also known as Channa striata), catfish Clarias batrachus, gourami Trichogaster trichopterus, T. pectoralis, gobies Glossogobius giurus, climbing perch Anabas testudineus, barbs Puntius spp. and other freshwater fish species. EUS is currently defined as a seasonal epizootic condition of freshwater and estuarine warm water fishes of complex infectious etiology characterized by the presence of invasive Aphanomyces sp. and necrotizing ulcerative lesions that typically lead to a granulomatous response (Roberts et al. 1994a). However, the mechanism of EUS development, especially that of its outbreak in nature, has not yet been fully clarified.

Studies on horizontal transmission of EUS under natural conditions have consistently shown that the disease can be transmitted naturally (Balasuriya et al. 1990, Cruz-Lacierda \& Shariff 1995), suggesting the infectious nature of the disease. The bacterium Aeromonas hydrophila and the pseudofungi Aphanomyces 
sp. have been associated with EUS-affected fishes (Llobrera \& Gacutan 1987, Boonyaratpalin 1989, Costa \& Wejeyaratne 1989, Torres 1990, Lio-Po et al. 1992, Roberts et al. 1993, Pathiratne et al. 1994, Angka et al. 1995, Callinan et al. 1995, Karunasagar et al. 1995, Willoughby et al. 1995, Lilley \& Roberts 1997, Igbal et al. 1999, Rahman et al. 1999). In addition, previous studies have demonstrated the presence of rhabdovirus among fishes affected with EUS in the Philippines (Lio-Po et al. 2000). In Thailand, Myanmar and Sri Lanka, the ulcerative disease rhabdovirus (UDRV) and the snakehead rhabdovirus (SHRV) were likewise isolated from EUS-affected snakeheads (Frerichs et al. 1986, Ahne et al. 1988, Kasornchandra et al. 1992, Lilley \& Frerichs 1994, Kanchanakhan et al. 1999).

The objective of this study was to investigate the horizontal transmission of EUS-associated virus in snakeheads under natural conditions.

\section{MATERIALS AND METHODS}

Experimental fish. Healthy snakeheads, 30 to $80 \mathrm{~g}$, were collected from ponds in Iloilo, Panay Island. These had been cultured for about 2 mo from fry caught from the wild by the fish farmer. During the holding period, EUS was not observed, nor has EUS been reported on Panay Island. The fish were transported to the Tigbauan Station of the Southeast Asian Fisheries Development Center (SEAFDEC). Samples of the fish were assayed for the presence of the virus before the experiments were begun, and tested negative for the virus. Thus, these were considered naïve fish. The fish were acclimatized at ambient temperature $\left(28\right.$ to $\left.32^{\circ} \mathrm{C}\right)$ for at least $1 \mathrm{wk}$ in $1000 \mathrm{l}$ fiberglass tanks before being transported by air to the SEAFDEC Binangonan Freshwater Station in Laguna de Bay. The transport water contained $10 \mathrm{mg} \mathrm{l}^{-1}$ tricaine methane sulfonate (MS222). At the Binangonan Station, the fish were again acclimated in separate $1.5 \times 3 \times 2 \mathrm{~m}$ concrete tanks with fresh aquifer water (from underground or deep well water at the experimental site, beside the Laguna de Bay lake where EUS is endemic) for $1 \mathrm{wk}$ before the experiments.

Experimental set-up. We placed 20 healthy, naïve snakeheads in each of 2 net cages $(1 \times 1 \times 1 \mathrm{~m})$ suspended in 4 separate concrete tanks $(3 \times 3 \times 1.5 \mathrm{~m})$. Experimental groups consisted of (A) aquifer water, (B) lakewater, (C) lakewater stocked with Grade III and IV naturally EUS-affected fish, and (D) lakewater stocked with apparently healthy snakeheads.

We placed 1 EUS-affected or apparently healthy fish, between 250 and $900 \mathrm{~g}$, in each of 8 smaller net cages $(0.3 \times 0.5 \times 0.5 \mathrm{~m})$ immediately adjacent to each larger cage containing the naïve fish. The tanks were filled with water the day before the experiment, and the
EUS-affected and apparently healthy fish were placed into them $2 \mathrm{~h}$ before stocking with the naïve fish. Lakewater, EUS-affected fish and apparently healthy snakeheads were taken from Laguna de Bay at the peak of the EUS outbreak during December 1994 to February 1995. Naturally EUS-affected snakeheads that died after stocking in the smaller net cages were replaced during the first week of the experiments but no replacement was made thereafter. The experiments were run for 25 d, from 16 January to 10 February 1995.

Monitoring. All tanks/cages were checked daily for fish mortality and development of EUS-like lesions (morbidity). Lesions were graded according to the criteria in Table 1. Mortalities among naturally EUSaffected and apparently healthy snakeheads in smaller net cages were also monitored. Water temperature was recorded twice daily, at 08:00 and 17:00 h. Fish were fed with cooled, previously steamed marine fish.

Sampling for virus detection. Experimental fish were sampled for virus isolation on Days 0, 10, 20 and 25 following initiation of the experiment. Naïve snakeheads, naturally EUS-affected snakeheads, fish with healing EUS lesions, and apparently healthy snakeheads were also sampled. From each fish, tissues were excised from lesions in the muscle, liver, gonad, kidney, spleen and gills. Excised tissue samples were separately immersed in Leibovitz medium with 200 I.U. penicillin $\mathrm{ml}^{-1}$ and $200 \mu \mathrm{g}$ streptomycin $\mathrm{ml}^{-1}$ medium, and stored at $-70^{\circ} \mathrm{C}$ until processed.

Each tissue sample was diluted to $10 \%$ (Chong et al. 1990) with Eagle's balanced salt solution (EBSS) containing an antibiotic/antimycotic (ab/am) mixture (200 I.U. penicillin-G sodium, $200 \mu \mathrm{g}$ streptomycin sulfate, $50 \mathrm{\mu g}$ amphotericin-B ml ${ }^{-1}$ medium) and homogenized with a mortar and pestle. The homogenates were centrifuged at $3000 \times g$ for $15 \mathrm{~min}$ at $4^{\circ} \mathrm{C}$, filtered through a $0.45 \mu \mathrm{m}$ pore-size membrane filter (Millipore) and stored at $-70^{\circ} \mathrm{C}$ until assay.

Table 1. Ophicephalus striatus. Classification of epizootic ulcerative syndrome (EUS)-like lesions in experimentally exposed snakeheads

\begin{tabular}{|c|c|}
\hline Lesion grade & Lesion characteristics \\
\hline Normal & Normal, intact skin \\
\hline Grade I & $\begin{array}{l}\text { Scale loss with slight erosion of the skin } \\
\text { surface with or without hemorrhagic spots }\end{array}$ \\
\hline Grade II & $\begin{array}{l}\text { Eroded dermal layer that may be } \\
\text { hemorrhagic }\end{array}$ \\
\hline Grade III & $\begin{array}{l}\text { Ulcerated dermal layer with exposed } \\
\text { underlying musculature }\end{array}$ \\
\hline Grade IV & $\begin{array}{l}\text { Frankly necrotic ulcers with extensively } \\
\text { eroded/sloughing underlying musculature, } \\
\text { at times emitting foul odor }\end{array}$ \\
\hline
\end{tabular}


Tissue culture and viral assay. For primary virus isolation, filtrates were inoculated onto monolayers of channel catfish ovary (CCO) cells in MEM with $4 \%$ fetal bovine serum (MEM-4) buffered with $1 \mathrm{M} \mathrm{N}$-2-hydroxyethylpiperazine-N'-2 ethanesulfonic acid (HEPES) at $25^{\circ} \mathrm{C}$ for $7 \mathrm{~d}$. All media were adjusted to $\mathrm{pH} 7.2-7.4$ with $7.5 \%$ sodium bicarbonate and were supplemented with ab/am mixture. These were microscopically examined daily for cytopathic effects (CPE). Blind passages were carried out on negative samples on at least 3 occasions.

Statistical tests. Morbidity and mortality data were processed using a repeated-measures analysis of variance followed by Duncan's multiple-range test.

\section{RESULTS}

The lesion development in naïve snakeheads is summarized in Fig. 1. The development of EUS-like lesions was most rapid in naïve snakeheads exposed to naturally affected EUS snakeheads in lakewater (Treatment C) or with apparently healthy snakeheads in lakewater (Treatment D). The onset of lesions was observed on Days 6 (Treatment C) and 7 (Treatment D), with $100 \%$ morbidity on Days 12 and 14 post-exposure, respectively. In lakewater alone (Treatment B), the onset of the disease was slower, with the initial lesions occurring on Day 16 and 100\% morbidity observed on Day 21 post-exposure. Naïve fish stocked in aquifer water alone (Treatment A), however, did not develop EUS-like lesions until the termination of the experiment. Differences in rates of lesion development among treatments were highly significant $(p<0.01)$. The rate and number of naïve fish developing EUS-like lesions in Treatments C and D were significantly faster and higher than in the other treatments from Days 6 to 16 post-exposure. Also, the morbidity rates in the lakewater treatment (B) were statistically different $(\mathrm{p}<$ 0.05 ) from those of the control fish in aquifer water (Treatment A) at $20 \mathrm{~d}$ post-exposure.

EUS signs began as Grade I lesions then gradually advanced to Grades III and IV in 4 to $5 \mathrm{~d}$ from their onset (cf. Tables $1 \& 3$ ). The periods of lesion progression were consistent for naïve fish in lakewater and for naïve fish cohabiting with EUS fish and with apparently healthy fish in lakewater (Treatments B, C and $D$, respectively). The gross pathology of the lesions was similar to that of the naturally affected EUS fish, with single or (more often) multiple lesions and ulcers developing on the head, caudal, dorsal, ventral and/or lateral musculature (Fig. 2). There was no common pattern observed as to sequence or preferential anatomical site of lesion development. Several naïve snakeheads exposed to EUS fish and apparently healthy snakeheads in Treatments $\mathrm{C}$ and

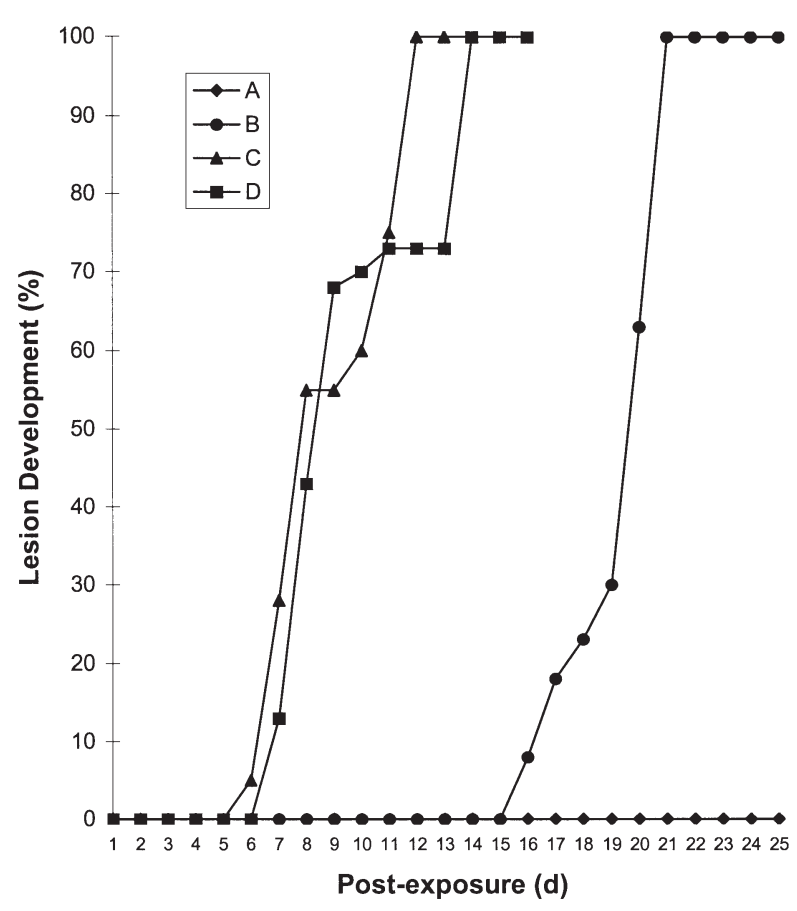

Fig. 1. Ophicephalus striatus. Lesion development among naïve snakeheads stocked in (A) aquifer water, (B) lakewater, (C) lakewater containing snakeheads with epizootic ulcerative syndrome (EUS), and (D) lakewater containing apparently healthy snakeheads

D had very pale gills when sampled. In all experimental samples, including EUS-affected and apparently healthy snakeheads, EUS lesion development occurred in both male and female fish, including gravid females.

Mortality was acute among naïve snakeheads stocked in lakewater (Treatment B), cohabiting with EUS fish in lakewater (Treatment C), and cohabiting with apparently healthy snakeheads in lakewater (Treatment D) (Fig. 3). However, mortality in Treatment B occurred later than in Treatments C and D. Naïve fish in aquifer water (Treatment A) also showed some mortality.

The water temperature during the experiments ranged from 23 to $24.5^{\circ} \mathrm{C}(08: 00 \mathrm{~h})$ and 24 to $25^{\circ} \mathrm{C}$ $(17: 00 \mathrm{~h})$ during the first $6 \mathrm{~d}$ and then from 24 to $26.5^{\circ} \mathrm{C}$ $(08: 00 \mathrm{~h})$ and 25 to $28.5^{\circ} \mathrm{C}(17: 00 \mathrm{~h})$ until Day 25 (Fig. 4).

Our results further confirmed that naïve snakeheads were free of virus at the start of the experiments (Table 2). Naturally EUS-affected snakeheads were positive for virus in all organs tested. Snakeheads with healing lesions from natural water also tested positive for virus in the liver. Among apparently healthy snakeheads, however, only 1 out of 8 test fish were infected. In naïve fish, the virus was 
detected at 10 d post-exposure in EUS fish in lakewater, and in apparently healthy fish in lakewater (Treatments $\mathrm{C}$ and D). The virus was also detected among naïve snakeheads in aquifer water and in lakewater (Treatments A and B) on Day 20 of the experiment. The virus was detected in all organs sampled, with higher rates for the liver, kidney and spleen than for the other tissues.
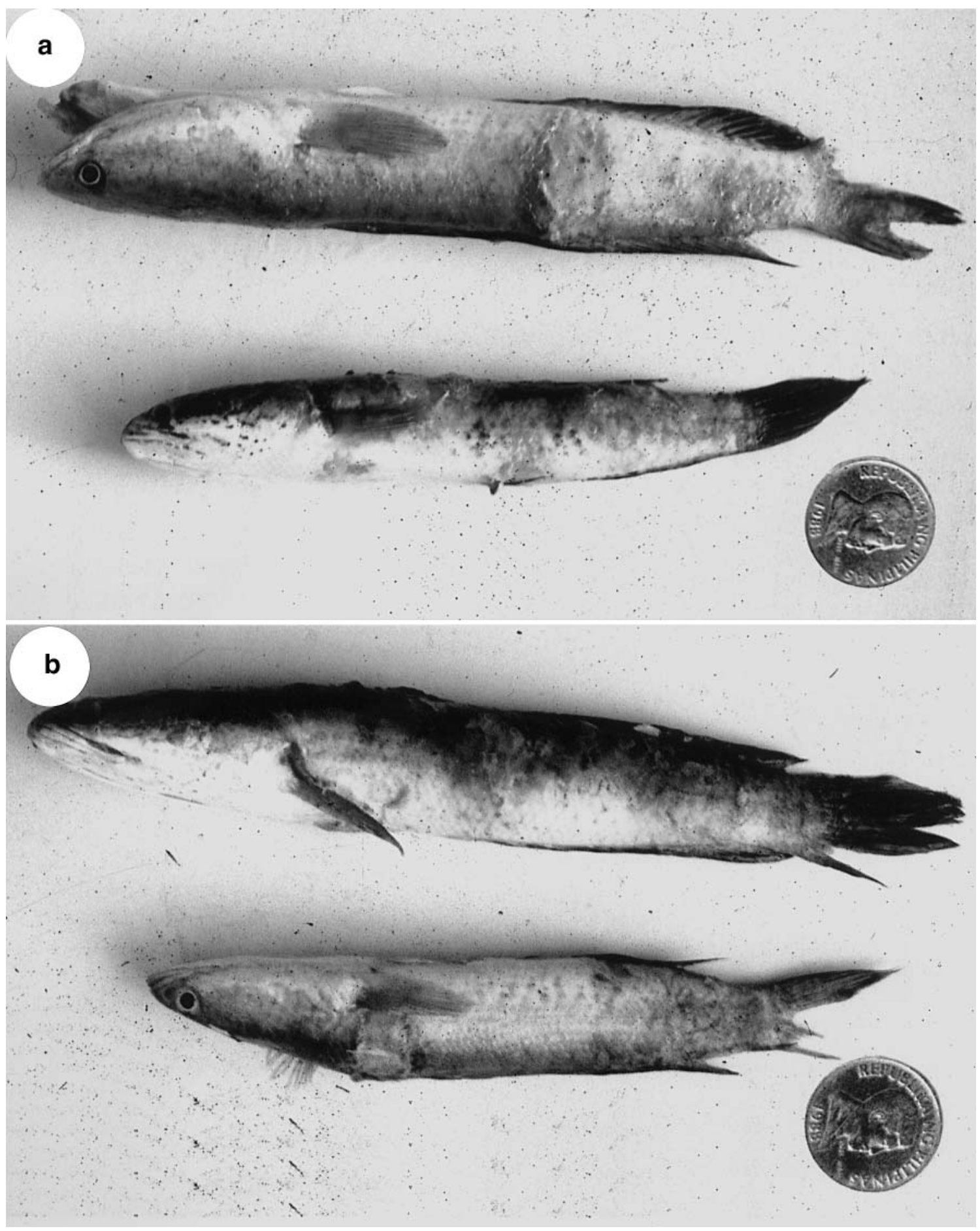

Fig. 2. Ophicephalus striatus. Snakeheads showing EUS-like lesions following exposure to (a) lakewater with EUS-affected snakeheads, and (b) lakewater with apparently healthy snakeheads. Coins are $20 \mathrm{~mm}$ in diameter, and included for scale purposes 


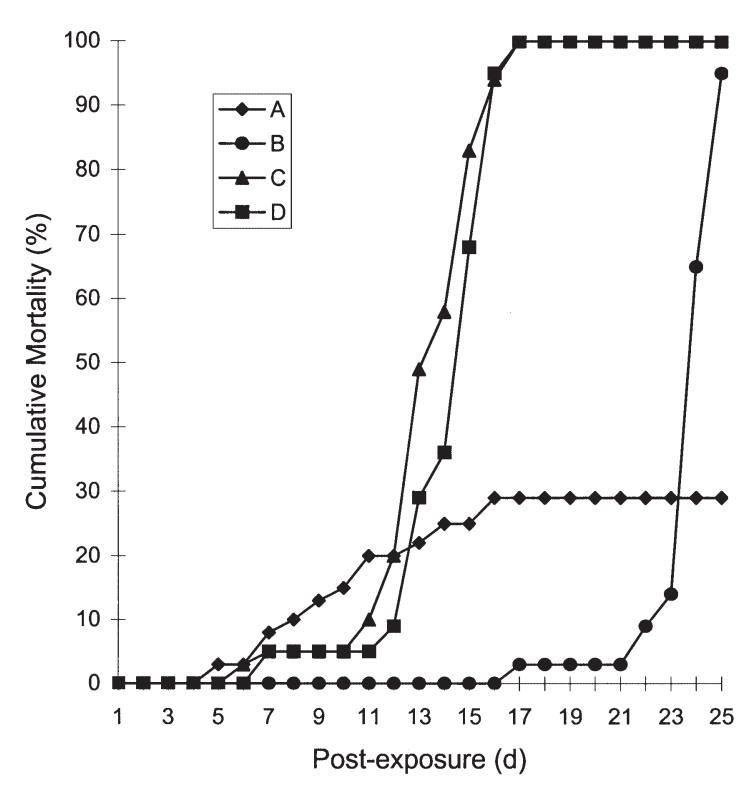

Fig. 3.Ophicephalus striatus. Cumulative mortality among 20 naïve snakeheads stocked in (A) aquifer water, (B) lakewater, (C) lakewater with EUS-affected snakeheads, and (D) lakewater with apparently healthy snakeheads

\section{DISCUSSION}

Previous cohabitation studies on EUS using snakeheads also produced EUS-like lesions (Balasuriya et al. 1990, Cruz-Lacierda \& Shariff 1995). The latter study was conducted at the same site as the present study, and histopathological analysis revealed that the experimentally induced EUS lesions were similar to natural

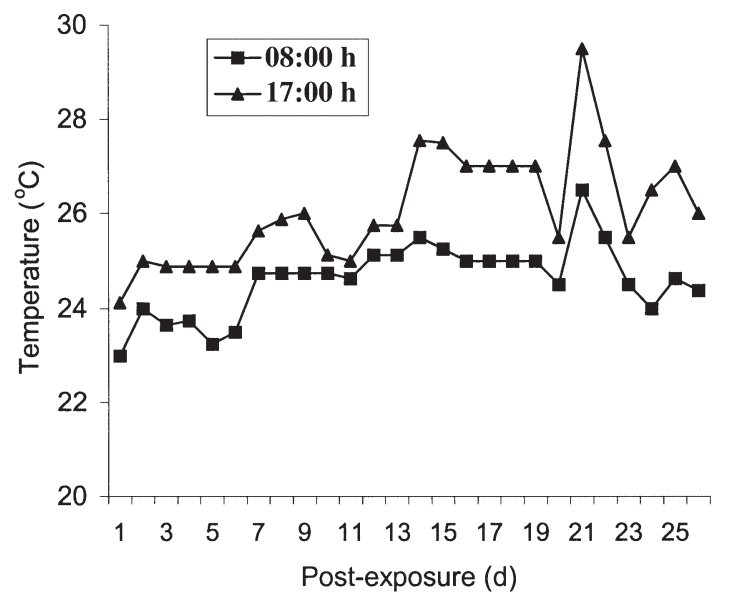

Fig. 4. Water temperature during EUS horizontal transmission experiments with snakeheads Ophicephalus striatus

EUS lesions (Lacierda 1995). These results indicate that EUS infection is waterborne, and suggest that an infectious agent is probably involved in its transmission. However, no microbial isolations were conducted in both studies. In the present experiment, EUS-like lesions likewise readily developed in naïve fish either cohabiting with EUS-affected fish or apparently healthy snakeheads or in naïve fish maintained in lakewater in which EUS was present. Furthermore, the EUS virus was transmitted from the EUS-affected or apparently healthy fish to the naïve snakeheads.

Recovery of the virus by tissue culture from experimentally EUS-exposed fish under the simulated natural conditions of the present study is a new finding. The

Table 2. Ophicephalus striatus. Isolation of EUS-associated virus from different organs of snakeheads following cohabitation exposure in aquifer water and in Laguna de Bay water during EUS season. Values show number of fish testing positive/number sampled (passage number at which cytopathic effect was observed). A: reared in aquifer water; B: reared in lakewater; C: cohabiting with EUS snakeheads in lakewater; D: cohabiting with apparently healthy snakeheads in lakewater; Total: number of virus detections per fish sample; -: no virus detected; nt: not tested

\begin{tabular}{|c|c|c|c|c|c|c|c|c|}
\hline Snakehead sample & Sample no. & Muscle & Liver & Gonad & Kidney & Spleen & Gills & Total \\
\hline Naïve & 6 & - & - & - & - & - & - & - \\
\hline Naturally EUS-affected & 6 & $2 / 6(1 \sim 2)$ & $4 / 6(1 \sim 4)$ & $1 / 6(4)$ & $3 / 6(1 \sim 4)$ & $3 / 6(1 \sim 2)$ & $\mathrm{nt}$ & $4 / 6(1 \sim 4)$ \\
\hline With healing lesion ${ }^{a}$ & 2 & - & $1 / 2(1)$ & - & - & - & - & $1 / 2(1)$ \\
\hline Apparently healthy ${ }^{\mathrm{a}}$ & 8 & $1 / 8(1)$ & - & $1 / 8(1)$ & $1 / 8(1)$ & $1 / 8(1)$ & $1 / 8(1)$ & $1 / 8(1)$ \\
\hline A (Day 10) & 6 & - & - & - & - & - & - & $0 / 6$ \\
\hline (Day 20) & 6 & $1 / 6(4)$ & $2 / 6(4)$ & $3 / 6(2 \sim 4)$ & $3 / 6(4)$ & $3 / 6(2 \sim 4)$ & $2 / 6(3 \sim 4)$ & $3 / 6(2 \sim 4)$ \\
\hline (Day 25) & 5 & - & - & - & - & - & - & $0 / 5$ \\
\hline B (Day 10) & 6 & - & - & - & - & - & - & $0 / 6$ \\
\hline (Day 20) & 6 & $4 / 6(3 \sim 4)$ & 1/6 (1) & $2 / 6(2 \sim 3)$ & $3 / 6(3 \sim 4)$ & $4 / 6$ (3) & $3 / 6(2 \sim 4)$ & $4 / 6(1 \sim 4)$ \\
\hline (Day 25) & 2 & - & - & - & - & - & - & $0 / 2$ \\
\hline C (Day 10) & 6 & $2 / 6(1)$ & $3 / 6(1 \sim 3)$ & $2 / 6(1 \sim 4)$ & $4 / 6(1 \sim 4)$ & $1 / 6(4)$ & $1 / 6(4)$ & $4 / 6(1 \sim 4)$ \\
\hline D (Day 10) & 6 & - & $3 / 6(1 \sim 4)$ & $2 / 5(4 \sim 5)$ & $1 / 6(1)$ & - & - & $3 / 6(1 \sim 5)$ \\
\hline
\end{tabular}


virus was found to be serologically related to the EUS rhabdovirus by neutralization tests using polyclonal antisera raised against the EUS rhabdovirus isolate, as described in a previous study (Lio-Po et al. 2000). The overall success rate in viral isolations among experimental snakeheads in this study was $21 \%$, although Fig. 1 shows that lesion development occurred in all naïve fish in Treatments B, C and D. In contrast, previous studies reported a 5 and $0 \%$ isolation rate of virus from EUS fish in Thailand and Bangladesh, respectively (Frerichs 1994). In addition, in previous unpublished studies, we found that EUS fish with lesions of Grades I and II yielded a highly significant $(\mathrm{p}<0.0005)$ success rate for virus isolation compared to more severely lesioned EUS fish (Grades III or IV). Likewise, Kanchanakhan et al. (2002) recently reported that the frequency of re-isolation of the EUS rhabdovirus after experimental infection of healthy snakeheads was 50 to $75 \%$ on Day 7, 0 to $50 \%$ on Day 14 and 0 to $25 \%$ on Day 30. Since viral isolations in the present study were conducted on Days 10, 20 and 25, this may explain our low virus recovery rates.

Naïve snakeheads both cohabiting with EUSinfected fish in lakewater (Treatment C) and those kept in lakewater alone (Treatment B) developed EUSlike lesions with concomitant mortality, and the virus was recovered from these experimentally infected fish. Furthermore, lesion development and concomitant mortality occurred much earlier in Treatment $\mathrm{C}$ than in Treatment B. These results imply that both EUSaffected fish and lakewater contained the virus, which effectively infected the naïve fish. It is plausible that the EUS-affected fish shed virus actively into the water, and therefore the titer of virus in the water of Treatment $C$ was higher than that in the water of Treatment $\mathrm{B}$, and thus required a shorter incubation period to infect fish than Treatment B (Table 3).

Almost similar morbidity and mortality rates were observed in naïve snakeheads cohabiting with EUS fish in lakewater (Treatment C) and those cohabiting with apparently healthy fish in lakewater (Treatment D). These results imply that both EUS-affected fish and apparently healthy fish carry and shed the virus into the water. This hypothesis is supported by the fact that the virus was isolated from apparently healthy fish (Table 2).

In naïve snakeheads kept in lakewater (Treatment B), in those cohabiting with EUS fish in lakewater (Treatment C) and with apparently healthy snakeheads in lakewater (Treatment D), the infection progressed to prevalence rates of $100 \%$ (Fig. 1). Close examination of the results shows that the interval between lesion onset to manifestation of severe lesions was about $5 \mathrm{~d}$ in Treatments B, C and D, although the onset of lesions in Treatments $\mathrm{C}$ and $\mathrm{D}$ was much ear- lier than in Treatment B (Table 3). Consequently, death from the time of lesion onset was consistently observed in 5 or $6 \mathrm{~d}$, with more than $50 \%$ mortality occurring $8 \mathrm{~d}$ after lesion onset (Figs. 1 \& 3, Table 3). Hence, it appears that although the incubation period for the onset of EUS lesions differed in Treatment B vs C or D (depending on the source of viral contamination), once the lesions clinically appeared the pathological process of the disease followed a similar pattern over the same number of days.

In the present experiment, the virus was isolated from both male and female fish, including gravid females. Together with the isolation of the virus from the ovaries of EUS-affected fish, this suggests that vertical transmission of the EUS virus may be possible. It may also partially explain the persistence of EUS virus in fish populations in enzootic sites resulting in annual outbreaks of EUS.

In previous studies on EUS, viral isolations used pooled tissues (Frerichs et al. 1986, Lio-Po et al. 2000). However, in the present study, the virus was recovered from all test organs, indicating that the EUS virus is not organ-specific. In addition, the virus was also isolated in some naïve fish kept in aquifer water (Treatment A), although lesion development was not observed in this group. The reason for the presence of the virus in these fish is not clear. However, the fact that the virus tested positive only after blind passages indicates or suggests a low virus titer (Table 2). A dose-response experiment on the EUS rhabdovirus in an earlier study showed that a minimum of $10^{3} \mathrm{TCID}_{50} \mathrm{ml}^{-1}$ is required to induce dermal lesions in naïve snakeheads (Lio-Po et al. 2001). It is possible that the aquifer water was not absolutely 'virus-free' and that some viral particles present in the lake water may eventually have infiltrated the aquifer water and initiated subclinical infections of the naïve fish in Treatment A. Also, accidental aerosol contamination cannot be totally excluded (Wooster \& Bowser 1996). Additional confirmative and detailed study of this aspect may be necessay.

Natural transmission of EUS in the present study occurred at the low water temperatures that prevail

Table 3. Ophicephalus striatus. Summary of initial onset of EUS lesions (days), onset of severe lesions (days after initial lesion detection) and onset of mortality (days after onset of moderate lesions) among naïve snakeheads following treatments described in Figs. 1 \& 3. -: no lesions observed

\begin{tabular}{|lccc|}
\hline Treatment & $\begin{array}{c}\text { Initial lesion } \\
\text { onset }\end{array}$ & $\begin{array}{c}\text { Severe lesion } \\
\text { onset }\end{array}$ & Mortality \\
\hline A & - & - & - \\
B & $16-17$ & $4-5$ & 6 \\
C & $6-7$ & $5-6$ & $5-6$ \\
D & 7 & 5 & $5-6$ \\
\hline
\end{tabular}


during seasonal EUS outbreaks. The critical role of temperature in the pathogenesis of the EUS-associated virus was experimentally confirmed by the fact that the virus demonstrated its pathogenicity at rearing water temperatures of 20 to $22.5^{\circ} \mathrm{C}$ but not at 28 to $32^{\circ} \mathrm{C}$ (LioPo et al. 2001). This may partially explain why EUS outbreaks predominantly occur during the cooler season in the tropics.

In EUS-affected fish, the rhabdovirus, the bacterium Aeromonas hydrophila and the pseudofungi Aphanomyces invadans were most frequently associated with the disease. Pure cultures of the EUS-associated rhabdovirus were experimentally shown to induce slight to moderate skin lesions (Grade III) in all tested naïve snakeheads at rearing water temperatures of 20 to $22.5^{\circ} \mathrm{C}$, but not at 28 to $32^{\circ} \mathrm{C}$ (Lio-Po et al. 2001). Kanchanakhan et al. (2002) reported similar experimental skin lesion induction by the rhabdovirus in snakehead fish. Natural EUS lesions, however, are more advanced, commonly with ulcers (Roberts et al. 1994b). Our findings in this study confirm that the EUS virus was transmitted from EUS-affected or apparently healthy fish to healthy, naïve snakeheads. It is plausible to surmise that the transmitted virus initiated dermal lesions in the latter fish. However, since the EUS rhabdovirus can only induce slight to moderate lesions (Grade III) (Lio-Po et al. 2001), the observed Grade IV lesions were probably a result of secondary infection.

Earlier studies showed the consistent association of the bacterium Aeromonas hydrophila with EUS fish displaying advanced lesions (Grade IV) (Llobrera \& Gacutan 1987, Boonyaratpalin 1989, Costa \& Wejeyaratne 1989, Torres 1990, Lio-Po et al. 1992, Pathiratne et al. 1994, Angka et al. 1995, Karunasagar et al. 1995, Rahman et al. 1999). A. hydrophila can also induce ulcerative dermal lesions in experimentally challenged EUS-susceptible fish at both low and ambient temperatures (Lio-Po et al. 1992, Pathiratne et al. 1994, Angka et al. 1995, Karunasagar et al. 1995, Leaño et al. 1996, Lio-Po 1998, Aoki 1999). Previous studies also confirmed the presence of $A$. hydrophila in Laguna de Bay waters (Lio-Po et al. 1992), the site of the present study. Moreover, cytotoxin-producing strains of $A$. hydrophila were associated with EUS-affected fish and hypothesized to play an important role in the pathogenesis of the disease by Yadav et al. (1992).

In challenge experiments, the pseudofungi Aphanomyces invadans induced red hemorrhagic lesions at the site of injection of most experimental snakeheads at 19 and $26^{\circ} \mathrm{C}$, with granuloma development at the latter higher temperature, while fish at the lower temperature showed acute inflammation (Chinabut et al. 1995). Roberts et al. (1993) and Lilley \& Roberts (1997) showed that EUS-associated Aphanomyces sp. isolates induced mild local inflammatory lesion in snakeheads followed by severe invasive myonecrosis, and that these isolates grew faster at $31.5^{\circ} \mathrm{C}$ than at 18,21 or $24^{\circ} \mathrm{C}$. Catap \& Munday (1998) observed that sand whiting Sillago ciliata injected with zoospores of Aphanomyces sp. at $26^{\circ} \mathrm{C}$ developed highly inflamed, hemorrhagic external lesions, while similarly treated fish held at $17^{\circ} \mathrm{C}$ displayed only slightly inflamed injection sites.

The foregoing studies established the pathogenicity of each of these 3 pathogens: rhabdovirus, Aeromonas hydrophila and Aphanomyces sp. Roberts et al. (1993) hypothesized that a viral component to the disease complex is necessary to precipitate invasion by the pathogenic Aphanomyces sp. Therefore, more studies, including multiple or combination challenges of EUSsusceptible fish, are required to clarify the role of each in the pathogenesis of EUS.

This study is the first report of the horizontal transmission of EUS virus from EUS-affected and apparently healthy snakeheads to naïve snakeheads under simulated natural conditions. The finding was confirmed by the recovery of the EUS virus from naïve snakeheads experimentally exposed to either EUSaffected or apparently healthy fish.

Acknowledgements. Research funding was provided by the Aquaculture Department, Southeast Asian Fisheries Development Center and the International Development Research Center (IDRC) of Canada (Fish Microbiology Project 3-P-881053-02). Thanks are also due to the SEAFDEC, Binangonan staff, and the Bureau of Fisheries and Aquatic Resources (Manila) for use of facilities; and to Vicente Balinas for statistical analyses. Finally, the authors thank Drs. J. Webster, T. P. T. Evelyn, J. A. Plumb and E. C. Lacierda for their critical comments, and most especially Dr. Y. Inui for his painstaking review and suggestions in revising the manuscript.

\section{LITERATURE CITED}

Ahne W, Jorgensen PEV, Olesen NJ, Wattanavijarn W (1988) Serological examination of a rhabdovirus isolated from snakehead (Ophicephalus striatus) in Thailand with ulcerative syndrome. J Appl Ichthyol 4:194-196

Angka SL, Lam TJ, Sin YM (1995) Some virulence characteristics of Aeromonas hydrophila in walking catfish (Clarias gariepinus). Aquaculture 130:103-112

Aoki T (1999) Motile aeromonads (Aeromonas hydrophila). In: Woo PTK, Bruno DW (eds) Fish diseases and disorders, Vol 3. Viral, bacterial and fungal infections. CABI Publishing, Oxon, p 427-453

Balasuriya KSW, Kulathilake M, Subasinghe R (1990) Preliminary investigations into the experimental transmission syndrome in fish in Sri Lanka. In: Hirano R, Hanyu I (eds) The Second Asian Fisheries Forum. Asian Fisheries Society, Manila, p 659-662

Boonyaratpalin S (1989) Bacterial pathogens involved in the epizootic ulcerative syndrome of fish in Southeast Asia. J Aquat Anim Health 1:272-276

Callinan RB, Paclibare JO, Bondad-Reantaso M, Chin JC, Gogolewski RP (1995) Aphanomyces species associated 
with epizootic ulcerative syndrome (EUS) in the Philippines and red spot disease (RSD) in Australia: preliminary comparative studies. Dis Aquat Org 21:233-238

Catap ES, Munday BL (1998) Effects of variations of water temperature and dietary lipids on the expression of experimental epizootic ulcerative syndrome (EUS) in sand whiting, Sillago ciliata. Fish Pathol 33:327-335

Chinabut S, Roberts RJ, Willoughby LG, Pearson MD (1995) Histopathology of snakehead, Channa striatus (Bloch), experimentally infected with the specific Aphanomyces fungus associated with epizootic ulcerative syndrome (EUS) at different temperatures. J Fish Dis 18:41-47

Chong SY, Ngoh GH, Chew Lim M (1990) Study of three tissue culture viral isolates from marine foodfish. Singapore J Prim Ind 18:54-57

Costa HH, Wejeyaratne JS (1989) Epidemiology of the epizootic ulcerative syndrome occurring for the first time among fish in Sri Lanka. J Appl Ichthyol 1:48-52

Cruz-Lacierda ER, Shariff M (1995) Experimental transmission of epizootic ulcerative syndrome (EUS) in snakehead, Ophicephalus striatus. In: Shariff M, Arthur JR, Subasinghe RP (eds) Diseases in Asian Aquaculture. II. Fish Health Section, Asian Fisheries Society, Manila, p 327-336

Frerichs GN (1994) Review of viruses described from the epizootic ulcerative syndrome. In: Roberts RJ, Campbell B, MacRae IH (eds) ODA (Overseas Development Administration) Regional Seminar on Epizootic Ulcerative Syndrome. AAHRI (Aquatic Animal Health Research Institute), Bangkok, p 109-127

Frerichs GN, Millar SD, Roberts RJ (1986) Ulcerative rhabdovirus in fish in South-East Asia. Nature 322:216

Igbal MM, Chowdhury MBR, Islam MA, Baqui M, Karim SMR, Tajima K, Ezura Y (1999) Seasonal fluctuations of motile aeromonads and pseudomonads in a cultured pond of mrigal Cirrhinus mrigala in Bangladesh. Asian Fish Sci 12:17-24

Kanchanakhan S, Saduakdee U, Areerat S (1999) Virus isolation from epizootic ulcerative syndrome-diseased fishes. Asian Fish Sci 12:327-335

Kanchanakhan S, Chinabut S, Tonguthai $\mathrm{K}$, Richards RH (2002) Epizootic ulcerative syndrome of fishes: rhabdovirus infection and EUS induction of experiments in snakehead fish. In: Lavilla-Pitogo CR, Cruz-Lacierda ER (eds) Diseases in Asian Aquaculture. IV. Fish Health Section, Asian Fisheries Society, Manila, p 383-394

Karunasagar I, Sugumar G, Karunasagar I (1995) Virulence characters of Aeromonas spp. isolated from fish affected by epizootic ulcerative syndrome. In: Shariff M, Arthur JR, Subasinghe RP (eds) Diseases in Asian Aquaculture. II. Fish Health Section, Asian Fisheries Society, Manila, p 307-314

Kasornchandra J, Engelking HM, Lannan CN, Rohovec JS, Fryer JL (1992) Characteristics of three rhabdoviruses from snakehead fish Ophicephalus striatus. Dis Aquat Org 13:89-94

Lacierda EC (1995) Histopathology and hematology of epizootic ulcerative syndrome (EUS)-positive snakehead (Ophicephalus striatus). PhD thesis, Faculty of Fisheries and Marine Science, Universiti Pertanian Malaysia, Malaysia

Leaño EM, Lio-Po GD, Dureza LA (1996) Virulence and production of extracellular proteins (ECP) of Aeromonas hydrophila associated with the epizootic ulcerative syndrome (EUS) of freshwater fish. Univ Philippines-Visayas J Nat Sci 1:30-38

Lilley JH, Frerichs GN (1994) Comparison of rhabdoviruses associated with epizootic ulcerative syndrome (EUS) with respect to their structural proteins, cytopathology and serology. J Fish Dis 17:513-522

Lilley JH, Roberts RJ (1997) Pathogenicity and culture studies comparing the Aphanomyces involved in epizootic ulcerative syndrome (EUS) with other similar fungi. J Fish Dis 20:135-144

Lilley JH, Callinan RB, Chinabut S, Kanchanakhan S, MacRae IH, Phillips MJ (1998) Epizootic Ulcerative Syndrome (EUS) Technical Handbook. Aquatic Animal Health Research Institute, Bangkok

Lio-Po G (1998) Studies on several virus isolates, bacteria and a fungus associated with epizootic ulcerative syndrome (EUS) of several fishes in the Philippines. PhD dissertation, Simon Fraser University, Burnaby, BC

Lio-Po GD, Albright LJ, Alapide-Tendencia EV (1992) Aeromonas hydrophila in the epizootic ulcerative syndrome (EUS) of snakehead (Ophicephalus striatus) and catfish (Clarias batrachus): quantitative estimation in natural infection and experimental induction of dermomuscular necrotic lesion. In: Shariff M, Subasinghe RP, Arthur JR (eds) Diseases in Asian aquaculture. I. Fish Health Section, Asian Fisheries Society Manila, p 461-474

Lio-Po GD, Traxler GS, Albright LJ, Leaño EM (2000) Characterization of a virus obtained from snakeheads Ophicephalus striatus with epizootic ulcerative syndrome (EUS) in the Philippines. Dis Aquat Org 43:191-198

Lio-Po GD, Albright LJ, Traxler GS, Leaño EM (2001) Pathogenicity of the epizootic ulcerative syndrome (EUS)associated rhabdovirus to snakehead Ophicephalus striatus. Fish Pathol 36:57-66

Llobrera AT, Gacutan RQ (1987) Aeromonas hydrophila associated with ulcerative disease epizootic in Laguna de Bay, Philippines. Aquaculture 67:273-278

Pathiratne A, Widanapathirana GS, Chandrakanthi WHS (1994) Association of Aeromonas hydrophila with epizootic ulcerative syndrome (EUS) of freshwater fish in Sri Lanka. J Appl Ichthyol 10:204-208

Rahman MH, Kar D, Barman NN (1999) Bacterial pathogens associated with epizootic ulcerative syndrome in fishes in Assam. Indian J Anim Sci 69:1083-1085

Roberts RJ, Willoughby LG, Chinabut S (1993) Mycotic aspects of epizootic ulcerative syndrome (EUS) of Asian fishes. J. Fish Dis. 16:169-183

Roberts RJ, Campbell B, MacRae IH (eds) (1994a) ODA Regional Seminar on Epizootic Ulcerative Syndrome held in Bangkok in 25-27 January 1994. Aquatic Animal Health Research Institute, Bangkok.

Roberts RJ, Frerichs GN, Tonguthai K (1994b) Epizootic ulcerative syndrome of farmed and wild fishes. In: Muir JF, Roberts RJ (eds) Recent advances in aquaculture. V. Institute of Aquaculture, Blackwell Science, Oxford, p 207-239

Torres JL (1990) Studies on motile Aeromonas spp. associated with healthy and epizootic ulcerative syndrome-positive fish. PhD thesis, Universiti Pertanian Malaysia, Malaysia

Willoughby LG, Roberts RJ, Chinabut S (1995) Aphanomyces invaderis sp. nov. the fungal pathogen of freshwater tropical fish affected by epizootic ulcerative syndrome. J Fish Dis 18:273-275

Wooster GA, Bowser PR (1996) The serological pathway of a fish pathogen: survival and dissemination of Aeromonas salmonicida in aerosols and its implications in fish health management. J World Aquacult Soc 27:7-14

Yadav M, Indira G, Ansary A (1992) Cytotoxin elaboration by Aeromonas hydrophila isolated from fish with epizootic ulcerative syndrome. J Fish Dis 15:183-189

Submitted: August 24, 2001; Accepted: June 3, 2003

Proofs received from author(s): November 11, 2003 